JILID 1

(घ) $\beta$

ARTIKEL

SEJUMLAHKATA

UNTUK NYALA

INDONESIA 


\section{Hikmah Covid-19 Bagi Literasi}

Oleh Gede H. Cahyana

Virus Corona baru (novel Coronavirus) penyebab wabah Covid-19 mengubah kehidupan manusia. Belajar, bekerja, bersekolah, beribadah, berdagang, bersikap dan berperilaku juga berubah. Muncul gaya hidup baru. Gaya hidup baru ini berlaku minimal selama pandemik atau selama vaksinnya belum ditemukan. Hingga akhir September 2020 belum bisa dipastikan oleh ahlinya kapan vaksin Covid-19 dinyatakan siap diberikan kepada manusia. Sambil menunggu kehadiran vaksin tersebut tentu semua aktivitas hidup manusia harus terus berlangsung tetapi dengan perubahan.

Dunia pendidikan misalnya, sudah berubah. Murid dan mahasiswa disuruh belajar di rumah masing-masing. Begitu juga guru dan dosen disuruh mengajar dari rumah. Hanya dalam kasus khusus saja guru dan murid boleh bertemu di sekolah dan wajib melaksanakan protokol baku kesehatan untuk Covid-19. Ada positifnya, yaitu guru, dosen, murid, dan mahasiswa menjadi makin akrab dengan internet. Akrab dengan e-mail, WA, Telegram, Zoom, Google Meet, Youtube, website, dan blog. Murid dan mahasiswa mengerjakan tugas dari guru dan dosen dengan bantuan platform media komunikasi dunia maya tersebut.

Dunia maya memiliki jutaan lembar naskah akademik untuk murid dan mahasiwa dari bermacam-macam bahasa yang bisa diunduh dari internet. Dunia baca makin bergairah. Dunia tulis terus bertambah. Murid dan mahasiswa kian intensif belajar menulis. Memang banyak yang hanya copy-paste, sekadar salin-tempel dalam menulis tugas-tugasnya tetapi dapat dimaklumi. Pada tahap awal biasanya seperti itu. Lama-lama mereka akan berubah seiring dengan kemampuan murid dan mahasiswa bahkan guru dan dosen dalam menulis artikel atau makalah (paper). Yang penting gairah membaca dan menulis di dunia maya terus meningkat selama wabah ini. Baca dan tulis harus dikondisikan bagai api nan tak kunjung padam. Selayaknya dikobarkan dan dibesarkan.

Membesarkan api baca tulis menemukan momentum yang tepat pada masa wabah ini. Tanpa Covid-19 belum tentu gairah membaca dan menulis bisa semasif ini. Skalanya nasional bahkan internasional. Nyaris semua negara mengatur ulang pola pembelajaran di sekolah-sekolah. Begitu pun Indonesia. Kalau tidak ada perintah dari pemerintah untuk Work From Home tentu "keterpaksaan" membaca dan menulis dengan sumber dari internet dan menggunakan fasilitas telepon seluler tidak bisa 
semarak seperti sekarang. Orang tua yang semula kurang paham internet akhirnya ikut-ikutan belajar dan mulai mengenal istilah-istilah di dunia maya.

Orang tua ikut membantu anak-anaknya mencarikan materi tugas sekolah sekaligus ikut belajar membaca dan memahami tugas anakanaknya. Tentu ini tidak bagus. Membuatkan tentu berbeda dengan mengajarkan. Namun ada juga orang tua yang pendidikannya tidak tinggi sehingga kesulitan membantu anak-anaknya dalam membuat tugas sekolah. Apapun itu, demikianlah faktanya. Bisa dipandang negatif bisa juga positif. Hikmahnya ada, yaitu orang tua menjadi makin dalam masuk ke dalam dunia literasi secara tidak disengaja. Mungkin banyak orang tua yang tidak sempat membaca dan menulis karena sibuk bekerja. Tetapi pada masa pandemik ini justru mereka memiliki banyak waktu menemani anaknya belajar, baik karena kewajiban work from home atau karena sedang dirumahkan oleh perusahaannya.

Yang juga menarik, ada orang tua ikut mendaftar menjadi anggota perpustakaan dunia maya, misalnya Perpustakaan Nasional. Awalnya mereka tidak tahu ada perpustakaan dunia maya seperti Perpusnas itu. Tetapi informasi selama wabah ini begitu masif sehingga sampai juga informasi tentang perpustakaan tersebut kepada mereka. Orang tua lantas ikut mencarikan materi makalah dan artikel untuk anak-anaknya. Tanpa Covid-19 belum tentu mereka menjadi anggota Perpusnas. Bukan karena tidak mau tetapi tidak ada alasan dan tidak tahu apa manfaatnya.

Tampaklah akibat positif Covid-19 ini, orangtua yang awalnya jauh dari buku menjadi makin dekat dengan buku. Banyak yang merasa kagum (surprised) akan kekayaan literasi di dunia maya. Mereka menjadi tahu bahwa buku, makalah, dan artikel hampir tak terbatas banyaknya. Tidak akan cukup waktu untuk sekadar membuka dan melihat-lihat halaman demi halaman, lembar per lembar. Apalagi membacanya. Tidak mungkin habis dibaca seumur hidup. Satu hari satu buku saja, maka dalam setahun hanya terbaca 365 buku. Sepuluh tahun hanya 3.650 buku. Sedangkan jumlah buku mencapai ratusan ribu judul di Indonesia dan jutaan judul di seluruh dunia.

Kekaguman ini berdampak positif pada perubahan pola pikir orang tua. Mereka antusias berselancar di dunia maya selama membantu anakanaknya dalam mengerjakan tugas sekolah. Sekaligus orang tua bisa relaksasi selama work from home. Tanpa disadari, orang tua menjadi senang membaca, minimal membaca tulisan di media sosial, media komunikasi antara orang tua murid di sebuah sekolah. Mereka juga mulai 
menulis, minimal menulis di media sosial tersebut. Mulai menulis argumentasi atas suatu masalah yang hadir di telepon selulernya. Ikut diskusi di grup WA orang tua di sekolah anak-anaknya.

Lama-lama maka obrolan dari mulut ke mulut itu beralih menjadi percakapan dari tulisan ke tulisan. Mulai menuangkan pikiran dalam bentuk tulisan meskipun banyak yang masih menuliskan kata yang diucapkan saat bercakap-cakap. Istilahnya adalah bahasa tutur yang ditulis. Relatif sulit dipahami karena tanpa titik koma dan sering kata-kata itu disingkat-singkat. Tetapi ini masih wajar-wajar saja, tidak apa-apa. Akan ada masanya kualitas menulis itu makin meningkat seiring dengan peningkatan frekuensi membaca, menganalisis tulisan, dan menulis ulang yang dibacanya.

Kembali ke perihal perpustakaan tadi. Tidak hanya Perpustakaan Nasional tetapi semua perpustakaan. Covid-19 juga memberikan hikmah untuk perpustakaan. Budaya literasi yang mulai bergairah ini perlu sertamerta disambut baik oleh pustakawan. Mulai dari pejabat terasnya hingga ke pustakawan junior. Mereka ikut memudahkan murid dan orang tua dalam mencari dan membaca sumber daya ilmu yang tersedia di perpustakaan. Perpustakaan konvensional biasanya melayani tamu yang berkunjung secara langsung dengan mengantarnya langsung ke rak yang dituju. Di rak itu pengunjung bisa menemukan buku, majalah, ensiklopedia dan lain-lain sesuai dengan yang diinginkannya. Tetapi pada masa wabah ini berbeda. Rak-rak buku itu kini adalah rak maya. Rak imajiner. Ada tetapi tidak kasat mata.

Agar buku-buku di rak yang bertingkat-tingkat dan berderet-deret itu dapat dibaca oleh murid dan orang tua di mana saja berada maka harus diubah wujudnya. Harus digital. Pustakawan dan tim teknologi informasi membantu mengubah semua buku fisik menjadi buku digital sehingga bisa diakses oleh siapa pun dan di mana pun dengan internet, baik lewat komputer maupun telepon seluler. Dengan demikian maka perpustakaan tetap bisa eksis sebagai lokasi sumber ilmu. Perpustakaan tetap menjadi sumber literasi (pustaka). Perpustakaan ikut menguatkan pendidikan dan ikut mencerdaskan kehidupan anak bangsa Indonesia seperti dicanangkan sejak puluhan tahun sebelum adanya internet.

Hikmah Covid-19 selanjutnya adalah pemberantasan buta huruf. Huruf adalah sarana dasar untuk masuk ke budaya literasi. Tanpa bisa membaca huruf maka tidak mungkin bisa masuk ke dalam budaya baca tulis, budaya literasi. Hingga saat ini masih ada orang tua yang buta aksara Latin. Boleh jadi pada saat murid belajar di rumah bersama orang tuanya 
ikut serta kakek dan neneknya yang masih buta huruf. Bisa jadi pengasuh anak di rumah tersebut ikut mendengar sambil mengasuh balita. Asisten rumah tangga juga ikut mendengar. Mungkin juga tukang kebun, tukang masak, tukang cuci ikut belajar, minimal ikut mendengar.

Apabila tidak ada Covid-19 maka belum tentu kakek dan nenek ikut melibatkan diri di dalam pendidikan cucu-cucunya. Bahkan di desa-desa masih ada bapak dan ibu yang juga belum lancar membaca huruf Latin, apalagi menulis atau mengetik di komputer. Komputer pun mereka belum punya. Telepon seluler pun hanya ada satu di dalam sebuah keluarga. Berita seperti ini pernah viral di media sosial dan ditayangkan di televisi. Inilah Indonesia, sikap dan perilaku tolong-menolong masih ada. Murid yang kesulitan dalam pembelajaran dengan internet dibantu oleh tetangganya. Semuanya berupaya membantu dengan bergotong royong.

Pembelajaran akhirnya dilaksanakan tidak di rumah tetapi di kantor desa. Ada juga di kantor kecamatan, di kantor polisi. Ada juga yang naik ke bukit agar mudah mendapatkan sinyal internet. Mereka beramai-ramai di bukit itu pada siang hari sehingga aman dari tindak kejahatan. Ada juga yang belajar di warung-warung kopi (kafe) yang memberikan akses internet gratis dan penggunaan komputer yang juga gratis. Ini umumnya terjadi di kota-kota besar dan sedang atau di kota kecamatan.

Yang juga ikut aktif akibat Covid-19 adalah dunia perdagangan buku pelajaran dan buku bacaan umum. Terutama penerbit buku yang sudah memiliki toko buku online. Ketika toko fisiknya sepi pengunjung atau sedikit pembeli bahkan ditutup sementara oleh pemerintah karena alasan Covid-19 maka toko buku online bisa buka selama 24 jam sehari. Toko online bisa menjadi alternatif solusi bagi bisnis buku yang lesu selama pandemik. Penerbit yang belum siap dengan toko online masih bisa ikut berjualan di lokapasar atau marketplace di dunia maya.

Penerbit juga bisa promosi buku lama dan buku baru lewat video di Youtube. Kegiatan bedah buku offline yang tetap menerapkan protokol kesehatan bisa dilansir di kanal Youtube. Begitu juga kegiatan diskusi buku yang dilaksanakan online di Zoom atau Google Meet bisa disebar di internet. Murid dan mahasiswa adalah konsumen utama buku yang dijual online ini, minimal pada saat ini, selama pandemik ini. Mereka belum puas atas makalah dan artikel yang tersedia gratis di dunia maya sehingga perlu membeli buku yang membahas materi tertentu. Apalagi mahasiswa pascasarjana, mereka wajib menelaah beberapa buku ajar (textbook) yang dibandingkan isinya dengan buku ajar yang lain. Hasil telaah ini ditulis dalam bentuk makalah kemudian dibahas di kelas. 
Apabila bukunya belum tersedia dalam bentuk e-book maka mereka membelinya secara online. Mereka menghubungi penerbit atau toko buku yang ada di internet lewat mesin pencari seperti Yahoo.com atau Google.com. Ada toko di dalam negeri, ada juga toko di luar negeri. Satu yang terkenal adalah Amazon.com. Dengan cara seperti ini maka penjualan buku fisik masih tetap berlangsung dan dikirimkan lewat jasa titipan kilat. Ada juga yang dikirim dengan jasa ojek online. Ternyata masih ada kehidupan di dunia perbukuan fisik meskipun aktivitas transaksinya di bawah jual beli pada masa sebelum terjadi wabah.

Adakah hikmah Covid-19 bagi penulis buku dan artikel, juga editor? Peluang rejeki ada di mana-mana. Penulis buku dapat memanfaatkan masa wabah ini dengan memberikan pelatihan menulis buku via online. Berbayar tentu saja. Tetapi harganya relatif terjangkau karena tidak perlu membayar sewa ruang rapat di hotel, tidak perlu penganan (snack) dan makan nasi, tidak perlu biaya transportasi, tidak perlu biaya untuk penginapan di hotel. Biayanya hanya untuk akses internet peserta masingmasing dan untuk honor atau penghormatan atas jasa yang diberikan oleh penulis. Peserta pun hanya membayar lewat transfer bank kepada penulis. Setelah itu, pada waktunya, yaitu hari tanggal dan pukul yang ditetapkan oleh penulis, maka pelatihan bisa dilaksanakan.

Peserta pun bisa belajar di rumah masing-masing bahkan bisa diikuti oleh suami/istri dan anak-anaknya. Bayar pelatihan untuk satu orang tetapi bisa diikuti dan didengarkan oleh semua orang yang hadir di rumah peserta pelatihan. Hemat, murah, ramai, meriah. Usai pelatihan semua anggota keluarga bisa mendiskusikan materi pelatihan sehingga pemahaman atas materi pelatihan semakin mantap. Keluarga seperti ini layak menjadi duta literasi keluarga karena sudah menghidupkan nilainilai kecendekiawanan (intellectuality).

Hal yang sama juga dialami oleh editor buku. Pelatihan editor buku atau editor artikel ilmiah populer, juga artikel ilmiah untuk diterbitkan di jurnal ilmiah bisa digelar via online juga. Semua dilaksanakan lewat internet. Penulis dan editor bisa saja dilakoni oleh satu orang yang sama tetapi umumnya oleh orang yang berbeda. Tersebut adalah dua profesi yang berbeda di dalam penerbitan buku dan jurnal ilmiah. Tetapi dua profesi ini sama-sama makin dibutuhkan pada masa pandemik Covid-19. Profesi editor memang relatif kurang dikenal oleh masyarakat. Jangankan masyarakat awam, kalangan guru dan dosen juga banyak yang belum tahu bahwa ada profesi penting di dalam penerbitan buku, yaitu editor (penyunting). 
Adapun dosen yang sering menulis di jurnal ilmiah biasanya sudah tahu ada profesi editor. Semua jurnal ilmiah pasti memiliki editor. Di penerbitan yang sudah mapan malah ada tim editor dan editor in chief. Profesi editor ini juga ada pada penerbitan berkala berupa majalah dan koran dan biasanya merangkap menjadi redaktur (redaksi). Majalah online dan koran online atau portal berita juga menjadi salah satu sumber rujukan bagi murid dan mahasiswa selama mengerjakan tugas sekolah dan kuliahnya.

Seperti halnya majalah dan koran edisi cetak, yaitu yang berupa kertas, kini majalah dan koran online juga semakin banyak. Malah ada kecenderungan jumlah pelanggan koran dan majalah terus berkurang. Oplah koran dan majalah terus susut di tengah peningkatan akses ke portal berita online. Artinya, budaya literasi masih tetap ada dan bahkan boleh jadi meningkat tetapi berpindah dari media konvensional ke media online. Migrasi ini menjadi keniscayaan pada masa revolusi industri 4.0 dengan basis media massa tanpa kertas (paperless).

Tidak hanya profesi penulis dan editor, profesi guru dan dosen juga memperoleh hikmah dari Covid-19 ini. Derajat kualitas guru dan dosen meningkat karena semakin banyak literatur yang dibacanya. Makin banyak juga yang harus ditulisnya. Lantaran tuntutan tugas pokok dan fungsinya, guru dan dosen dipaksa memiliki materi ajar yang bisa ditayangkan secara online. Minimal bisa dikirimkan kepada murid dan mahasiswa lewat $e$-mail atau WA.

Sebelum ada wabah Covid-19 mungkin tidak semua guru dan dosen memiliki materi yang berwujud file. Mayoritas guru dan dosen memiliki materi ajar berwujud buku, diktat, modul, fotokopi, atau materi yang ditulis di plastik mika yang memerlukan Over Head Projector $(O H P)$ pada saat digunakan di depan kelas. Semuanya adalah sarana kuliah dan pembelajaran untuk tatap muka di kelas. Kini semua itu harus diubah menjadi bentuk digital. Bentuk yang bisa dikirimkan dengan berbagai media komunikasi online.

Untuk profesi dosen, selain harus menyiapkan materi perkuliahan untuk mahasiswa, yaitu dharma pendidikan dan pengajaran, dosen juga harus menulis artikel penelitian yang diterbitkan di jurnal ilmiah. Ini masuk ke dalam dharma penelitian dari Tridharma. Pada masa normal lama biasanya dosen banyak menghabiskan waktunya dalam perjalanan menuju kampus. Waktunya juga habis untuk temu muka dan saling sapa di kampus. Tetapi selama wabah Covid-19 ini justru dosen dilarang ke kampus sehingga waktunya lebih banyak di rumah. 
Dosen memiliki waktu luang untuk selancar di lautan ilmu di dunia maya, mengumpulkan artikel dan menelaahnya. Dosen bisa menulis diktat, menulis modul, menulis buku, dan menulis artikel ilmiah dan ilmiah populer untuk diterbitkan di media masa seperti koran dan majalah. Dosen juga ikut kegiatan yang jarang atau bahkan belum pernah diikuti pada masa sebelum ada wabah, yaitu seminar di dunia maya. Webinar.

Dalam satu hari ada dosen yang bisa ikut tiga kali webinar. Memang lebih banyak dosen yang menjadi peserta tetapi tetap saja positif karena pasti ada ilmu yang diperolehnya. Bagi dosen yang sudah dikenal pakar di bidang ilmu tertentu maka bisa sebagai narasumber di dalam webinar. Ada juga webinar di kalangan terbatas, yaitu diikuti hanya oleh ahli-ahli di bidang ilmu tertentu. Semua ahli itu menjadi pembicara di dalam webinar untuk saling tukar informasi dan saling menyampaikan hasil riset atau penelitiannya.

Dengan demikian bisa dikatakan bahwa wabah Covid-19 ini seperti blessing in disguise bagi dunia pendidikan, bagi dunia literasi. Covid-19 sudah mengubah dunia literasi konvensional menjadi online. Slogan bahwa buku adalah jendela dunia masih tetap berlaku tetapi buku dalam format digital. Begitu juga artikel, makalah, modul dan lain-lain. Kegiatan berkunjung ke perpustakaan juga tetap ada tetapi berubah menjadi selancar di perpustakaan maya.

Apabila semua kekayaan perpustakaan bisa diubah menjadi digital maka perpustakaan maya akan berjaya. Begitu pula akan ada aktivitas membeli buku dalam wujud $e$-book. Menjual buku dalam wujud $e$-book. Meminjam buku di perpustakaan maya juga dalam wujud e-book. Termasuk kekayaan literasi masa lampau, manuskrip, tulisan di papyrus, di lontar, tulang, kayu dan lain-lain bisa diubah menjadi bentuk digital sehingga bisa dibaca, dilihat, diunduh di dunia maya.

Dengan demikian maka wabah Covid-19 ini sesungguhnya sedang menghidupkan pelan-pelan budaya literasi digital di seluruh dunia. Semua ilmu yang biasanya dibaca dengan memegang wujud fisiknya seperti buku, majalah, koran, jurnal, modul, diktat kini bisa diubah menjadi wujud digital sehingga makin banyak orang yang memperoleh manfaatnya. Semua orang bisa mengunduhnya khususnya oleh murid, guru, mahasiswa, dosen, dan peneliti.

Tidak hanya orang perorang yang mengunduhnya, tetapi lembaga pun seperti sekolah formal, informal, dan nonformal bisa mengunduh materi digital tersebut. Bisa tetap dimanfaatkan dalam bentuk digitalnya, bisa 
juga dicetak (print out) kemudian dijilid menjadi buku fisik seperti biasanya. Wabah Covid-19 tidak bisa dihindari tetapi hikmahnya tetap bisa diperoleh. Begitu banyak hikmah yang diterima oleh banyak orang dan profesi di bidang literasi. Bisa dibuat hipotesis bahwa dampak literasi digital bagi kehidupan masyarakat akan jauh lebih besar dan lebih luas daripada dampaknya apabila tidak terjadi wabah Covid-19. Ini hanya bisa dibuktikan sekian tahun ke depan. Akhir kata, setiap orang bisa menjadi agen pembangkit literasi di Indonesia hanya dengan rajin membaca buku, artikel, makalah, majalah, koran kemudian berusaha menuliskannya. Ikatlah ilmu dengan menuliskannya. *

\section{Penulis}

Gede H. Cahyana lahir di Tabanan Bali. Setelah selesai SMA dia kuliah di program sarjana dan program magister di Jurusan Teknik Lingkungan ITB. Ia mengajar di Universitas Kebangsaan di Bandung. Selain mengajar, dia juga menulis artikel ilmiah populer dan opini. Media massa yang memuat tulisannya adalah Pikiran Rakyat, Majalah Air Minum, Intisari, Kompas Jabar, Galamedia, Bandung Pos, Republika, Bali Post, dan jurnal ilmiah. Dia juga menulis buku berjudul PDAM Bangkrut? Awas Perang Air, Mencari Allah, dan menulis sebuah bab di buku Dari Citarum Untuk Indonesia: Dari Sungai Menuju Gelas. Dia menulis artikel dengan tema air, air limbah, sampah di blogspot https://gedehace.blogspot.com dan https://osf.io/e3zfg. 